\title{
Perspective in Cataloging
}

\author{
Henry Bartlett Van Hoesen is librarian of \\ Brown University Library, Providence.
}

$\mathrm{H}^{\prime}$ ABIT HAS built a sort of fence between cataloging and administration. I have been on both sides of this fence-and I still am. To say that this fence is one of hostility would be an exaggeration. It's something like this: One librarian, questioned about his cataloging department said, "Well, the catalog department turns out about so many books in its own fashion, and there's nothing you can do about it." He may be right, but I won't admit it. On the other hand, Dr. Bishop seems to dash our dream of selective cataloging with a realistic epigram: "I think it requires more sense and discrimination than are usually found in our cataloging departments." This may be true, but, again, I won't have it so.

Here are two examples of the opposing extremes. In a time of reduced budget and staff, one librarian ordered: "We must not pile up arrears. The catalog department must do the best it can, and books must be sent to the shelves within twenty-four hours of their receipt in the catalog department." Set against. this a head cataloger who shrugs her shoulders: "Yes we have thousands of arrears and they are increasing. If the university wants them cataloged, they'll have to find more money for it-that's all."

More recently, Dr. Branscomb's Teaching with Books ${ }^{2}$ appears to view the cata-

\footnotetext{
1 Paper read before the New York Regional Cata-

$\log _{2}$ Group, April 26, 1940 . sociation of American Colleges and A.L.A., 1940.
}

$\log$ exclusively as an obstacle to the use of books and, in talking about costs of library service and suggesting economies, makes cataloging costs his chief, almost his only, burden of complaint.

This attitude of mind and this manner of speaking make one who is astraddle the fence want to jump to the cataloger's side -if they will let him. Studies of the cost of cataloging have been based on the number of items cataloged, not on the use of the catalog. It is customary to distinguish between acquisition and cataloging on the one hand and service on the other, but does not the service begin with the use of the catalog? Inadequate as circulation statistics are, can they not be used as fairly for estimating the service contributed by the catalog as for estimating the service of the circulation division?

In Fremont Rider's "Library Cost Accounting," 3 cataloging labor cost is 70 cents per volume cataloged, circulation cost is 24 cents per volume of regular circulation, but if both are figured on the basis of regular circulation, the cataloging cost is only 33 cents as compared with 24 cents circulation cost. If one compares labor costs of acquisition, periodical checking, accessioning and cataloging, with labor costs of circulation, public use (reading and reference) and storage, the preparations services cost 50 cents and the public services 42 cents per volume of regular circulation. Then why the complaint about the high cost of cataloging?

And now I shall try to get back into

3 Rider, Fremont. "Library Cost Accounting." Library Quarterly 6:331-81, Oct. 1936. 
the role for which I am cast, get over on the other side of the fence, and hazard some answers to my own question. First, economies are necessary, urgently so at this time. In the second place, the function of the cataloging department is most difficult for the layman to understand. (The layman's private library needs no catalog; or only a very crude one.) ${ }^{4}$ The manufacturer's or tradesman's stock, though its items outnumber any library's, needs only an inventory, and that with a comparatively limited number of entries. Third, cataloging processes are most complex and intricate, and so, as my librarian friend said, it seems that nothing can be done about it-but as I have said, I won't have it that way. ${ }^{5}$ Finally, if it appears that the librarian can do nothing about it, it also sometimes appears that the catalogers don't want to do anything about it. This is severe treatment of the catalogers, which most of them do not deserve, but I am thinking of the cataloger whom I quoted.

After interesting myself in different organization plans and divisions of labor in the catalog department, and even in machinery (though I hate it) and in many other, more specific remedies, I have developed my own perspective successively from "short cataloging" to "selective cataloging," and from "selective cataloging" to "perspective in cataloging," for I won't have it that catalogers can't discriminate.

\section{Perspective on Work Accomplished}

The first phase of perspective is a perspective simply of work-work and accomplishment. I have always been so intent

"Cf. Hanson, J. C. M. "Sound and Unsound Economy in Cataloging." Library Quarterly 4:6575, Jan. 1934 .

"Cf. Osborn, Andrew D. "Cataloging Costs and a Changing Conception of Cataloging." Catalogers' and Classifiers' Yearbook, A.L.A., 1936, pp. 45-54. on getting a job done, once it was assigned, that I have had no time to worry about whether it was interesting or not-and I have dug ditches, pitched hay, and picked stones out of the road.

\section{Perspective on the Material Cataloged}

Following the perspective on work as an opportunity for satisfaction in accomplishment, there is the perspective of interest in the materials with which the work is concerned. Here cataloging books has an advantage over shoveling dirt. A German professor émigré, who took a job shelving books in a library, told me that the year he spent at it was the most interesting of his life, because he saw all the important new books as they came in, and all the important old books as they came from circulation. The cataloger has the advantage of being able to see inside the books. The cataloger is both accomplishing something and working with interesting materials.

\section{Perspective on People}

The third perspective is perspective on people. I have known persons who thought they would prefer the routine of circulation to that of cataloging, because they like to deal with people. In my own experience, I find the people I meet in cata$\log$ departments interesting personalities. It is the cataloger's perspective on his fellow-catalogers that makes his organization function flexibly and smoothly according to its personnel. And it is the cataloger's perspective on the varieties of people who use the library which determines the adaptability of cataloging results to their uses. One need not see the patrons as they charge out a book, or ask where the $W$ orld Almanac is, or where they left their hats. One can learn more about them from the 
books ordered for their use, from the courses they teach and from the books they write- "by their works shall ye know them." This is the perspective I meana sort of combined perspective on books and people, a perspective on the use-objective of the library catalog.

\section{Perspective on Financial Exigencies}

Finally, there is the financial perspective, and here the fault, where and if it exists, is most probably with the head cataloger, or the librarian, or the college administration. The college president cannot with propriety take every member of the college staff into his confidence on details of finances and budgets. The librarian is in a similar situation as regards the library staff. The chief cataloger cannot tell his assistant all he knows, whether of financial, educational or administrative policies. But they should all be able and willing to pass on enough of their perspective so that the staff member will want to be a cooperator, rather than a perfectionist, to go along with a new proposal as far as possible, to find ways over obstacles, not to magnify them. I once accused one of my staff of not wanting to change anything unless it would improve matters, while I wanted to change everything if it would improve matters. The two attitudes sound pretty much alike, but there is a world of difference between them. Miss MacPherson suggests this in "Some Thoughts on the Philosophy of Cataloging." 6

Now, grant, as you must, that the remedy of more money and still more money is not available in endowed institutions, and grant, as you should, that the high cost of cataloging must be reduced,

"MacPherson, Harriet D. "Some Thoughts on the Philosophy of Cataloging." Library Quarterly $9: 63-71$, Jan. I 939. and grant, as you probably will, that specific remedies have thus far not been generally effective, you will surely sympathize with my appeal for the cultivation of perspective on cataloging work as work, on the material cataloged, on cataloging personnel, on users and uses of catalog cards, and on the financial necessity of applying the various specific remedies with a maximum of gain in work accomplished and a minimum loss in usefulness to readers.

In achieving economies in organization, much depends on the size and flexibility of the staff as a whole, as well as on the flexibility and caliber of the individual members of it. One cataloger may organize himself quite simply and satisfactorily - granted full perspective-and two catalogers may agree to get on together, but it takes three to make a crowd-and several more, plus typists, filing assistants, etc., to make an organization flexible enough to experiment with divisions of work either by subject or by process. To introduce machinery you must have enough work to keep the machine busy, enough personnel to spare one person to operate the machine, and enough other people to profit by the machine's saving of time. For example, if enough of us have enough card duplication to do and enough staff to operate the machine and still leave typists and other junior assistants free to relieve the catalogers, then we will get the right kind of duplicating machine-one that will avoid the necessity of putting every card on the typewriter for addition of subject headings, added entries, etc. Then we can make use of such job analyses as Mr. Miller's. ${ }^{7}$

Some libraries with a staff sufficiently

${ }^{7}$ Miller, Robert A. "Cost Accounting for Libraries: Acquisition and Cataloging." Library Quarterly $7: 5$ I I-36, Oct. 1937 . 
large, flexible, and experienced have been able to make use of junior catalogers or typists to relieve catalogers of two of these items (searching and checking, and completion of cataloging) which, together, according to Miller, take 45 per cent of "direct labor time" in cataloging a new book.

\section{Chance for Economy}

Another useful breakdown of cataloging activities is Miss Akers' "Relation of the Professional and Clerical Division of Cataloging Activities to Cataloging Courses." ${ }^{8}$ For our purposes, we need to make four instead of two divisions: (I) supervision-i.e. chief cataloger, reviser, or first assistant; (2) cataloger; (3) junior cataloger (semi-professional) ; (4) clerical. Of course, the more divisions we make, the more they overlap one another and the more any division of labor must be kept flexible and adaptable to individual capabilities. Applying this four-fold division to Miss Akers' 72 professional activities indicates a good possibility of economy within the professional and semi-professional group, and some possibility of more profitable use of the time of the experienced clerical workers. If in a given library the clerical staff has been well developed over a period of years, it is possible that they may relieve the professional staff of 19 of their 72 activitiesonly, however, if the chief cataloger and her immediate assistants have a perspective on people (for psychoanalysis is fully as important as job analysis in personnel work), a perspective on the objectives of the catalog in the college milieu, and a perspective on the financial exigencies

s Akers, Susan Grey. "The Relation of the Pro. ities to Cataloging Courses." Library Quarterly $5: 101-36$, Jan. 1935 fessional and Clerical Division of Cataloging Activ-

of the institution and of the times. ${ }^{9}$

When clerical assistants, particularly typists, can be made to relieve catalogers' time for more expert work, the economy of typists' time becomes important. Twenty years ago, when I became interested in the possibilities of short cataloging and in the selective use of it, I was not concerned with the saving of typists' time nor with the congestion and unwieldiness of the card catalog, as I am now. When one of my superior officers said, "Every click of the typewriter costs money," I took the attitude of the old bridgetender who looked at the town clock and set the clock at one end of the bridge, then set the clock at the other end of the bridge, and denied that his two clocks could disagree, because he walked across the bridge "in no time." That is the way I felt about clicks of the typewriter (but with 30,000 arrears of typing, I don't feel that way any more). That may be the way the typist feels, and that's the way the cataloger feels-the way every perfectionist feels who takes pride in his work. Perhaps I should have listed two perspectives instead of four: a sense of time, and a perspective on the importance of details relative to their cost in time and money and to the use to be made of them. We say glibly, "Whatever is worth doing is worth doing well," but we should say, "Whatever is worth doing is worth doing well enough to serve the purpose for which it is undertaken." 10

Many suggestions have been made for economizing on the clicks of the typewriter. I shall note only a few of them.

\footnotetext{
- Cf. Gjelsness, Rudolph H., and Wright, Wyllis E. "Organization of the Preparation Division, New York Public Library." Catalogers' and Classifiers' Yearbook, I936, pp. 26-35."Preliminary Cataloging." College and Research Libraries $1: 235-40$, June 1940. College and Research Libraries 1 :235-40, June 1940. ${ }^{10} \mathrm{Cf}$. Smith, Esther A. "Form C.
logers and Classifiers" Yearbook, 1936.
}

SEPTEMBER, 1940 
I. Machines for reproducing cards. The chief obstacles are the expensiveness of some, the relatively impermanent and unsightly results of others, and the necessity of putting all the cards on the typewriter to add subject and added entriesunless or until the Library of Congress or other card printing agencies can supply complete sets of cards ready for filing. Meanwhile, suppose you have large arrears of typing and of cataloging and a lifetime's work of reclassification, at the same time urgent needs of added personnel in reference and other departments, and no reasonable prospect of additional appropriations. One might try the improved hektograph machines, buy the best, operate it as expertly as possible, and be satisfied if the results are no better than legible for twenty years. With the ditto machine, it is possible easily to pick up subject and added entries from the tracings on the master card and place them at the top of the respective additional cards.

2. Reduction in number of cards written. Bishop's statement, made nearly thirty years ago, on subject entries remains true today, and the situation is aggravated by the growing unwieldiness of card catalogs. At one time during the depression, the catalog at Brown University needed respacing. As an experiment I tried retiring cards that seemed to me unnecessary; the reference librarian revised my selection and approved removal of about 5 per cent of all the cards in the trays with which we experimented. The catalogers soon asked, "Should we write and file cards that are going to be retired ?" ard I replied, "You shouldn't but I don't know how to stop you." They then took over the experiment, with the result that now we probably use not more than two-thirds as many subject cards as the Library of
Congress, and not half as many title cards.

This is a difficult undertaking, lacking any code. The only safe solution that I can suggest is a study of some large cata$\log$ with the Library of Congress list of subject headings in hand. Such a case study would result in many unforeseen economies I am sure, and one can foresee profitable comments on the too specific subject as a most unlikely place to look, on the piling up of "related" subjects that might be eliminated in favor of references, on the duplication of titles under headings which refer to each other, on the unnecessary subject cards for research material that will be consulted on the shelves or via the shelf list. ${ }^{11}$ This is a case where one can't see the wood without having seen the trees-a case study is needed, and it could be combined with Osborn's suggestion of special subject lists by class.

3. Shortening of cards written.

Headings. We have been amused at our own Lincoln collection catalog, where some 3000 cards are headed "Lincoln, Abraham, pres. U.S., I 809-1869." (b) The other contents of the card. There are too many details to discuss here, and nothing new to say about them and the limited applicability of omission or abbreviation, but by special request, here is an illustrative problem:

There are many kinds of periodicals, used in different ways-all the way from the most authoritative learned journal, down to the house organ, and pulp magazines, and advertising and propaganda sheets, which are used, if at all, to see what they or their sponsoring organizations are like and of which "enough is as good as a feast." Falling heir to some 3000 volumes of trade association and

\footnotetext{
1 Hitchcock, Jennette Eliza. "Subject Coverage in University Library Catalogs." Library Quarterly Io:69-94, Jan. I940.
} 
trade union journals and newspapers only more or less complete, would you throw them out against what the department of instruction alleges and what you believe to be their interest? Would you tackle the impossible job of completing them, spend five thousand dollars on binding them and another thousand or so on cataloging them? How would you meet the suggestion that you "don't bother to cata$\log$ them but just arrange them somewhere on the shelves where we can find them"? The perfectionist who would say "all or none" would be lacking in perspective on subject matter of books, on the people likely to use them, and on the catalog as a tool for these users. ${ }^{12}$

\section{Selective Cataloging}

I have been a disciple of the late Ernest Cushing Richardson and while I think some of his reasoning and mathematics fallacious and some of his proposed remedies worse than the disease, he was one of the great philosophers of our profession. It is always a temptation to quote him. Take this from his startling paper on "The Curse of Bibliographical Cataloguing:"

A study of printed cards in the Union Catalog shows a great percentage of books that oughtn't to be in existence at all, except for very remote bibliographical purposes, and extremely remote specialized research for which a single short author card at two and four-tenths cents would be quite sufficient. ${ }^{13}$

There remains a question which I have put before-whether, since the order department of a research library is not permitted to apply the principles of book selection, may not the catalog department apply these principles to the selection of

${ }^{12}$ Smith, Esther A. loc. cit. "The Curse of Bibliographical Cataloguing." American Library Institute. I93 I.

SEPTEMBER, 1940 books for prompt and complete cataloging, as against books which may be deferred or cataloged more briefly.

To sum up, the librarian alone can have the broad perspectives that come from contacts with the administration and faculty on the one hand, and with the library and library staff on the other. $\mathrm{He}$ may say to his faculty colleagues that they are entitled to tell him what they want, but not how to get it. It is his duty to pass on to his heads of departments as much as possible of his perspective on what is wanted, and he must depend on their cooperation to get it. It is the cataloger alone who can get results, and it is his duty to absorb as much perspective as he can, and, when he can't, to credit his superior officers with the perspective he has not. He must go along with them as far and as fast as is practicable- to be willing to change everything if it will improve matters. A sharing of perspectives on cataloging work; on books and their place in the college; on staff and readers; on the uses of cataloging results, and on what results the college can afford -this is the only cure for the high cost of cataloging. With this cumulative perspective, the many specific remedies invented already, or to be invented, may be applied with safety and curative effect. Head catalogers should keep fully up to date on specific devices: new tricks in organization and division of labor, and in cataloging economies. And they should not forget the old ones, since these may become applicable, and are suggestive of new inventions. Without perspective, the specific remedies are likely to fail of application, to be misapplied, to be applied in overdoses, to be given to the wrong patients-all to the ultimate aggravation, rather than the cure, of the high cost of cataloging. 